\title{
Study on Antibiotic Loaded Nanoparticles for Oral Infection Treatment
}

\author{
GEORGETA ZEGAN ${ }^{1}$, VASILICA TOMA ${ }^{1 *}$, EDUARD RADU CERNEI ${ }^{1 *}$, DANIELA ANISTOROAEI ${ }^{1}$, ELENA MIHAELA CARAUSU ${ }^{2}$, \\ MIHAELA MOSCU ${ }^{3}$ \\ ${ }^{1}$ Grigore T. Popa University of Medicine and Pharmacy, Faculty of Dental Medicine, Department of Surgery, 16 Universitatii Str., \\ 700115, lasi, Romania \\ ${ }^{2}$ Grigore T. Popa University of Medicine and Pharmacy, Faculty of Dental Medicine, Department of Management and Public \\ Health, 16 Universitatii Str., 700115, Iasi, Romania \\ ${ }^{3}$ Grigore T. Popa University of Medicine and Pharmacy, Faculty of Medicine, Department of Morphological and Functional \\ Sciences 1, 16 Universitatii Str., 700115, Iasi, Romania
}

\begin{abstract}
Over the past decade, exploitation of antimicrobial effect of nanoparticles on viruses, fungi and bacteria, respectively have developed markedly. A close attention was received by the possibility of nanoparticles type drug delivery systems to limit the biofilm formation within the oral cavity due to their important properties such as delivery abilities, anti-adhesive and biocidal features. The major objective of this work was to obtain doxycycline-loaded chitosan nanoparticles and to analyze the properties of as prepared samples in order to prolong the antibiotic release. The synthesized nanoparticles had less than $100 \mathrm{~nm}$ using the classis or improved drug encapsulation technique in chitosan matrix. The study focused on the antimicrobial characteristic of nanoparticles for controlling oral infections.
\end{abstract}

Keywords: doxycycline, nanoparticles, FTIR analysis, oral infections, orthodontics, pedodontics, public health dentistry, morphological.

Oral diseases are one of the most widely spread illnesses that affects people around the world being a major public health dentistry issue in many countries. These oral disorders have consequences on humans, communities and medical services in terms of psychological, social and economic features. Nowadays oral infections can modify teeth morphology due to the acute and chronical diseases. Children being more exposed to pathogen agents, these nanodelivery system can be applied even in orthodontics. Dental carries and periodontal diseases are characterized by deterioration of the teeth and inflammation and degradation of the teeth surrounding structures starting with bacterial invasion around the region between teeth and gums namely gingival sulcus. If left untreated, periodontal pockets can lead to deposition of tartar, finally resulting in the loss of teeth [1-12].

Doxycycline is an antimicrobial drug used to treat extracellular and intracellular infection caused by Gram() and Gram( + ) bacteria as well as spirochetes, Chlamydia, mycobacteria, mycoplasma [13, 14]. This antibiotic (fig.1) is one of the most prescribed medicine worldwide due to it's antibacterial effect on a various pathogens $[15,16]$. Usual administration of doxycycline may cause side effects resulting in tissues altering, cavities in the body and blood vessels.

Nanoparticulate antibiotic delivery carriers were designed for drug targeting to the affected site for better efficacy. Encapsulation of drugs in nanoparticles as delivery systems can improve their efficiency by enhancing their bioavailability, minimizing side effects and by facilitating the prolonged release of encapsulated drug [1719].

Chitosan (fig.1) appeared as a potential biomaterial for dental uses due to its special properties such as bioactivity, biocompatibility and antimicrobial [18-22]. In the form of nanoparticles, chitosan can be used to deliver drugs to periodontal tissues in situ against microbial infections. The antibiotic encapsulated chitosan nanoparticles have higher surface area and reactivity to facilitate drug release due to their bacteriostatic and bactericidal action for a wide variety of oral microorganisms [23, 24].

\section{Experimental part \\ Materials and methods}

Doxycycline, chitosan ant the other reagents were purchased from specialized producers.

Chitosan nanoparticles were obtained by ionic gelation method using different concentrations of polymer dissolved in acetic acid solution. Sodium tripolyphosphate solution (TPP) was prepared in distilled water then added drop wise with a syringe to the chitosan solution under stirring and followed by sonication for $20 \mathrm{~min}$. The suspension was centrifuged at $15000 \mathrm{rpm}$ for $15 \mathrm{~min}$. The resulting pellets were re-suspended in distilled water by sonication, centrifuged and then dried at room temperature.

Antibiotic-loaded chitosan nanoparticles were spontaneously formed by drop-wise addition of doxycycline to the chitosan solution before the TPP addition. Doxycycline encapsulated chitosan nanoparticles using $0.42 \% \mathrm{w} / \mathrm{V}$ TPP are reffered to as Doxy-CNPs4 and those

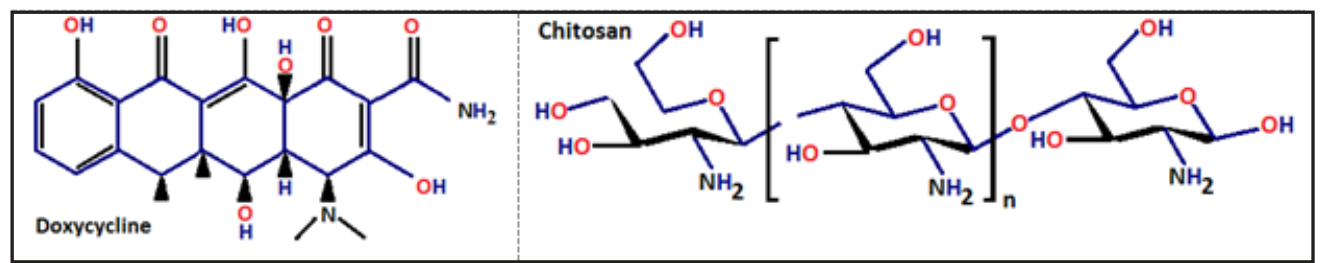

Fig.1. Schematic

representation of doxycycline and chitosan 
prepared using $0.60 \% \mathrm{w} / \mathrm{V}$ TPP are refered to as DoxyCNPs6. All nanoparticles analyses were performed by advanced characterization techniques.

\section{Results and discussions}

Particle size distribution was determined measuring dynamic lightscattering by particles in solution. The analysis consists of suspension of nanoparticle samples in $1 \mathrm{ml}$ of pure water. The antibiotic -loaded nanoparticles DoxyCNPs4 (fig. 2A) have an average particles diameter of 45 $\mathrm{nm}$, spherical in shape with smooth edges. Similarly, the Doxy-CNPs6 particles ( fig 2B) have an average diameter of $280 \mathrm{~nm}$ exhibiting a very narrow particle size distribution feature, spherical and with not as smooth edges than the other sample.

It is well known that the more similar the particles are in size equally the antibiotic is distributed among the particles thus normalizing the rate of drug release.

FTIR spectra of doxycycline, chitosan and antibiotic loaded chitosan nanoaprticles are shown in figure 3.

Doxycycline is characterized by the presence of a broad band at $3500-3100 \mathrm{~cm}^{-1}$ due to the $0-\mathrm{H}$ stretching vibration. Aromatic ring from doxycycline structure is expressed by aromatic $\mathrm{C}-\mathrm{H}$ stretching in the region $3000 \mathrm{~cm}^{-1}$. Strong absorption band at $920 \mathrm{~cm}^{-1}$ is due to out of plane bending of $\mathrm{C}-\mathrm{H}$ bonds. The band at $1700 \mathrm{~cm}^{-1}$ is attributed to the presence of carbonyl group stretching $(C=0)$ while absorption band at $1250 \mathrm{~cm}^{-1}$ is due to the $\mathrm{C}-\mathrm{C}-\mathrm{C}$ stretching and $\mathrm{C}-\mathrm{C}(=0)-\mathrm{C}$ bending. Amide group in the doxycycline structure are confirmed by amide I band due to carbonyl absorption at $1650 \mathrm{~cm}^{-1}$ and amide II band due to $\mathrm{N}-\mathrm{H}$ bending at $1570 \mathrm{~cm}^{-1}$ but N-H stretching bands overlaps with the $0-\mathrm{H}$ stretching bands in the $3500-3100 \mathrm{~cm}^{-1}$ area. Strong absorption at $1090 \mathrm{~cm}^{-1}$ is assigned to C-N stretching of amine group.
FTIR spectrum of chitosan nanoparticles presents intense broad band in $3600-3150 \mathrm{~cm}^{-1}$ area due to $\mathrm{O}-\mathrm{H}$ stretching vibrations. The $\mathrm{C}-\mathrm{H}$ stretching vibration are at $2900 \mathrm{~cm}^{-1}$ and $\mathrm{N}-\mathrm{H}$ stretching vibrations connects with $\mathrm{O}$ $\mathrm{H}$ stretching vibration in the domain $3600-3150 \mathrm{~cm}^{-1}$. N-H bending of amine is at $1650 \mathrm{~cm}^{-1}$ and $\mathrm{C}-\mathrm{N}$ stretching is present at $1080 \mathrm{~cm}^{-1}$.

Peak of C-O-C present at $1030 \mathrm{~cm}^{-1}$ is attributed to glucopyranose ring while absorption band in region 1150 and $900 \mathrm{~cm}^{-1}$ is assigned to $\beta(1-4)$ glycosidic bridge.

Antibiotic was released from doxycycline -loaded chitosan nanoparticles in a burst effect way follow ed by a slow, controlled release (fig. 4). For Doxy-CNPs4 the burst effect happened within the first 5 hours and for Doxy-CNPs6 within the first $4 \mathrm{~h}$. The amount of drug release lowered being followed by a controlled release for the remaining time.

Doxy-CNPs6 released more antibiotic amount than DoxyCNPs4 by the end of the $24 \mathrm{~h}$ monitoring period. This difference can be due to the differences in particle size. The burst effect followed by slow controlled release is perfect for treating microbial infections.

Antibacterial activity of doxycycline encapsulated chitosan nanoparticles (presented in fig. 5) was evaluated by minimum inhibitory concentrations (MIC) and minimum bactericidal concentration (MBC).

Results revealed that after four hours incubation at $37^{\circ} \mathrm{C}$, the antibiotic-loaded nanoparticles MIC of doxycycline was

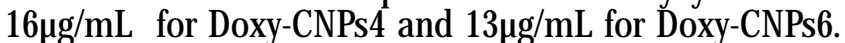
For both samples more than $90 \%$ bacteria growth inhibition was observed.

MBC was $48 \mu \mathrm{g} / \mathrm{mL}$ for Doxy-CNPs4 and $40 \mu \mathrm{g} / \mathrm{mL}$ DoxyCNPs6. If the incubation period was extended beyond $4 \mathrm{~h}$, the nanoparticles antibacterial activity would have been higher than unencapsulated doxycycline.
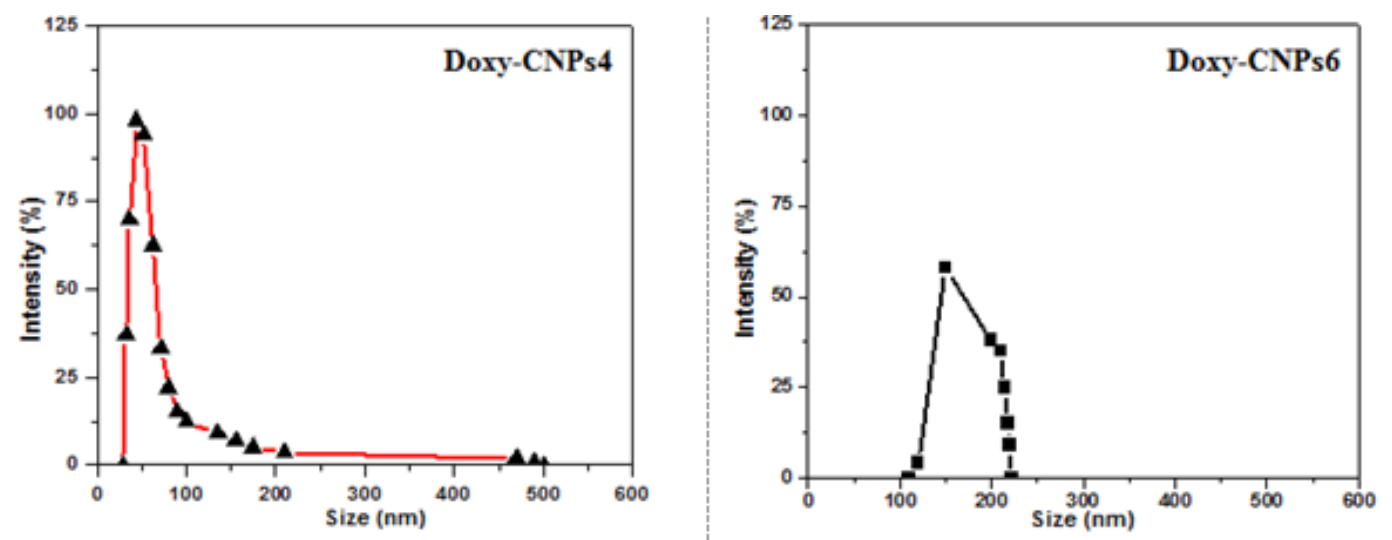

Fig. 2. Particle size distribution for antibiotic loaded-chitosan nanoparticles: Doxy-CNPs4 and Doxy-CNPs6

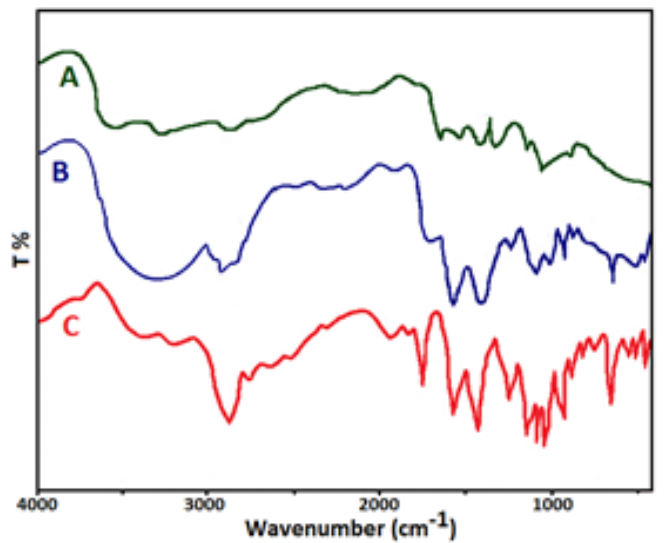

Fig. 3. FTIR spectra of (A) Chitosan (B) Doxycycline and (C) Doxy-CNPs.

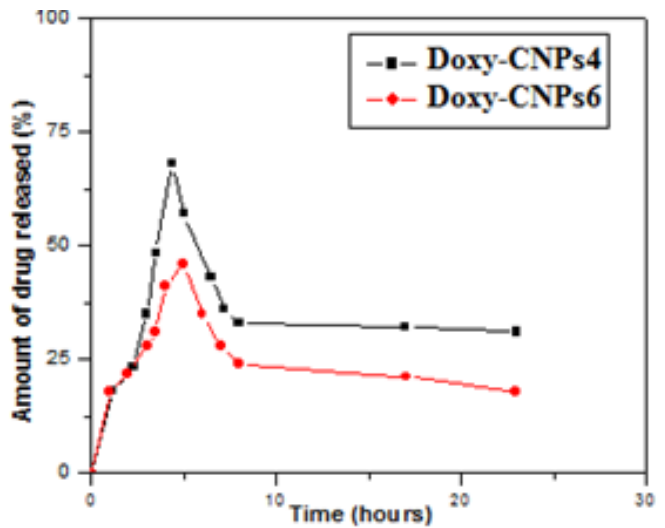

Fig. 4. The amount of antibiotic release over a 24-h period for Doxy-CNPs4 and Doxy-CNPs6. 


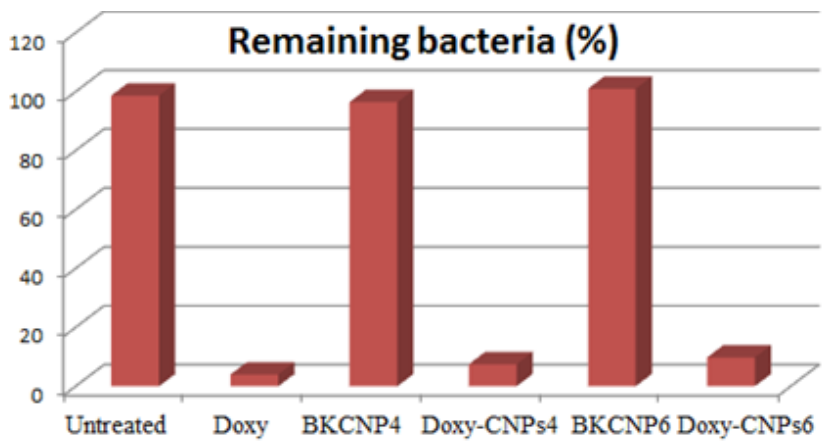

Fig. 5. Inhibitory effects of antibiotic-encapsulated chitosan nanoparticles on bacterial growth, in terms of percentage of remaining bacteria after $4 \mathrm{~h}$ of treatment

\section{Conclusions}

Chitosan is a biomaterial for dental uses in different ways such as restorative dentistry, tissue engineered scaffolds, alveolar bone and periodontal complex healing, respectively. This study reveals a nanoparticulate formulation of doxycycline-encapsulated chitosan nanoparticles for oral infections treatment indicating the enhanced efficiency of novel drug delivery system on pathogen agents. Doxycycline-loaded chitosan nanomaterials were synthesized and characterized for exploring characteristics that may improve antibiotic delivery and efficacy.

The results suggested that this formulation has the potential to control oral infections in a sustained manner which a strategy for biofilm-associated acute and chronic infection treatment. Therefore, clinical dental application need further researches especially in vivo studies and clinical investigations.

\section{References}

1.PIHLSTROM, B.L., MICHALOWICZ, B.S., JOHNSON, N.W., Lancet, 366, 2005, p. 1809.

2.DIAS, R.J., HAVALDAR, V.D., GHORPADE, V.S., MALI, K.K., GAIKWAD, V.K., KUMBHAR, D.M., J App Pharm Sci, 6, 2016, p. 200.

3.PETERSEN, P.E., OGAWA, H., Periodontol 2000, 60, 2012, p. 15.

4.BATCHELOR, P., Br Dent J , 217, 2014, p. 405.
5.ALI, M.S., ALI, J., AHUJA, A., ALAM, M.S., J App Pharm Sci, 2, 2012, p. 114.

6.AMINU, N., BABOOTA, S., PRAMOD, K., SINGH, M., DANG, S., ANSARI, S.H., SAHNI, J., ALI, J., J Nanoparticle Res, 15, 2013, p. 2075.

7.CHEN, X., WU, G., FENG, Z., DONG, Y., ZHOU, W., LI, B., BAl, S., ZHAO, Y., Crit Rev. Biotechnol., 36, 2016, P. 760.

8.OSORIO, R., ALFONSO-RODRÍGUEZ, C.A., MEDINA-CASTILLO, A., ALAMINOS, M., TOLEDANO, M., PLoS One, 11, 2016, e0166217.

9.ZAMANI, M., MORSHED, M., VARSHOSAZ, J., JANNESARI, M., Eur. J. Pharm. Biopharm, 75, 2010, p. 179.

10.KESAVALU, L., SATHISHKUMAR, S., BAKTHAVATCHALU, V., MATTHEWS, C., DAWSON, D., STEFFEN, M., EBERSOLE, J.L., Infect Immun, 75, 2007, p. 1704.

11.PRAMOD, K., AMINU, N., ALI, J.,. Biotechnology, 8, 2014, p. 97.

12.TANNER, A.C., J Oral Biosci., 57, 2015, p. 18.

13.RIOND, J., RIVIERE, J., Vet Hum Toxicol., 30, no. 5, 1988, p. 43.

14.J OSHI, N., MILLER, D.Q., Arch Intern Med., 157, no. 13, 1997, p. 1421.

15.CUNHA, B.A., DOMENICO, P., CUNHA, C.B., Clin. Microbiol. Infect., 6, no. 5, 200, p. 270.

16.ANGELAKIS, E., ARMSTRONG, N., NAPPEZ, C., ET AL. Infect, 71, 2015, p. 511.

17.TILAKARATNE, A., SOORY, M., Infect Disord Drug Targets 14, 2014, p. 14.

18.ZEGAN, G., CARAUSU, E.M., GOLOVCENCU, L., BOTEZATU-SODOR, A., CERNEI, E.R., ANISTOROAEI, D., Rev. Chim.(Bucharest), 69, no. 2, 2018, p. 321.

19.ZEGAN, G., CERNEI, E.R., CARAUSU, E.M., GOLOVCENCU, L., ANISTOROAEI, D., Rev. Chim.(Bucharest), 70, no. 4, 2019, p. 1215.

20.DE CARVALHO, M., STAMFORD, T., PEREIRA, E., DOS SANTOS, P., SAMPAIO, F., Formatex, 13, 2011, p. 2012,

21.KONOVALOVA, M.V., MARKOV, P.A., DURNEV, E.A., KUREK, D.V., POPOV, S.V., VARLAMOV, V.P., J. Biomed. Mater. Res.Part A, 105, 2017, p. 547.

22.CHEN, M., M.I., F., LIAO, Z., SUNG, H., CHITOSAN, In Chitosan for Biomaterials I; Springer: Berlin/Heidelberg, Germany, 2011, p. 185. 23.SAMPRASIT, W., KAOMONGKOLGIT, R., SUKMA, M.;, ROJ ANARATA, T., NGAWHIRUNPAT, T., OPANASOPIT, P., Carbohydr. Polym., 117, 2015, p. 933.

24.LI, W., MAUCK, R.L., TUAN, R.S., J. Biomed. Nanotechnol., 1, 2005, p. 259

$\overline{\text { Manuscript received:3.09.2018 }}$ 